\title{
LEGAL REGULATION OF EPIDEMIC SECURITY UNDER THE COVID-19 PANDEMIC CONDITIONS IN SOME POST-SOVIET COUNTRIES AND POLAND
}

DOI: $10.36740 /$ WLek202012210

\author{
Yuliia Yu. Zabuha', Tetiana O. Mykhailichenko², Svitlana V. Rak ${ }^{3}$ \\ 'YAROSLAV MUDRYI NATIONAL LAW UNIVERSITY, KHARKIV, UKRAINE \\ ${ }^{2}$ POLTAVA LAW INSTITUTE OF YAROSLAV MUDRYI NATIONAL LAW UNIVERSITY, POLTAVA, UKRAINE \\ ${ }^{3}$ UKRAINIAN MEDICAL STOMATOLOGICAL ACADEMY, POLTAVA, UKRAINE
}

\begin{abstract}
The aim: To reveal the features of the epidemic safety and security legal regulation in Belarus, Kazakhstan, Moldova, Poland, Russia and Ukraine during the COVID-19 pandemic. Materials and methods: This study is based on Belarusian, Kazakh, Moldavian, Polish, Russian and Ukrainian regulatory acts as well as national court judgments. Such methods as dialectical, comparative, analytic, synthetic, comprehensive, statistical and generalization approaches have been used in the article.

Conclusions: the study confirmed that the direct impact on the spread and dynamics of morbidity during the COVID-19 pandemic in the countries to be analyzed is determined by: the presence of government agencies and special institutions involved in combating, preventing and monitoring the spread of infectious diseases and their readiness for effective measures in emergency situations caused, in particular, by epidemics; timeliness and duration of quarantine restrictions, their severity and scope; observance of these restrictions by the population; effectiveness of law enforcement responses to violations. The strengthening of administrative and/or criminal liability had no significant impact on the morbidity situation in the country.
\end{abstract}

KEY WORDS: public health, epidemic security, SARS CoV-2 pandemic, quarantine restrictions, liability

Wiad Lek. 2020;73(12 p. II):2758-2767

\section{INTRODUCTION}

Epidemic security is an important component of each state's national security. Despite the development of the world, outbreaks of epidemics occur on the regular basis: the rapid pace of people movement across the world leads to the rapid spread of disease. Thus, only in the beginning of the $21^{\text {st }}$ century the world had already experienced a pandemic of influenza A/H1N1 (01.2009-08.2010) ${ }^{1}$, epidemics of Severe Acute Respiratory Syndrome (SARS), H5N1 (HPAI A (H5N1), Middle East respiratory syndrome coronavirus (MERS-CoV), Ebola, Zika, etc. Also, as noted in the literature, "Old diseases - Cholera, Plague, Yellow fever among them - often return, and new ones invariably arrive to join them". About 40 outbreaks of cholera alone are reported to WHO every year [1, p. 15], the epidemics of HIV/AIDS and tuberculosis continue to date. The latest pandemic in the world is the COVID-19 coronavirus pandemic (caused by the rapid spread of SARS-Cov-2 virus) has shown how quickly epidemics and pandemics can modify the "face of the world", suspending most of our usual social processes ${ }^{2}$. As rightly noted, "the threat to global health has reached alarming proportions and has exposed a lack of national preparedness and international solidarity" [2, p .1521]. Such situations emphasize the fact that the health of the population is the key to the functioning of all the important areas/processes in each state: from the effective operation of government agencies to the state of the economy. The same provisions are noted by F. Alazzam, K. Aldrou, R. Moiseyenko, V. Mykhalchuk, Y. Radysh, A. Saleh [2, p. 1522; 3, pp. 995].

In response to the threat most countries urgently tightened state control over migration processes, restricted tourism and services to prevent the deterioration of the situation due to foreign visitors, outbreak and spread of

\footnotetext{
${ }^{1}$ Although the debate initiated by Wolfgang Wodarg regarding the falsity of the decision to declare this pandemic, which was supported by the Parliamentary Assembly of the Council of Europe on October 5, 2010, continues, the WHO did not agree with this criticism [4]. According to the official data, 18,500 people died during the A/H1N1 influenza pandemic, and the diagnosis was laboratory confirmed [5], while researchers suggested that between 151,700 and 575,400 people had died using mathematical simulations [6].

${ }^{2}$ A clear confirmation was achieved: "The sudden influx of large numbers of sick individuals to health facilities stretches the systems' capacity and resources, even more so and more noticeably where resources are already scarce" $[1$, p. 21]. Since the announcement of the Covid-19 pandemic, people with non-epidemic related health issues have found it more difficult to access health care. The same opinions were expressed in the WHO, noting that "many routine and elective services have been suspended... Disruptions to 24 -hour emergency room services for example were affected in $22 \%$ of countries, urgent blood transfusions were disrupted in $23 \%$ of countries, emergency surgery was affected in $19 \%$ of the countries" [7].
} 
COVID-19, as well as to provide conditions and tools for rapid and quality response to their emergence/spread, restricted trade, banned the export of medicines, medical products and equipment, etc. Some countries also increased administrative and/or criminal liability for violating the quarantine regime.

\section{THE AIM}

The purpose of this paper is to compare the legal regulation of epidemic security in the Republic of Belarus (hereinafter, RB), the Republic of Kazakhstan (hereinafter, RK), the Republic of Moldova (hereinafter, RM), the Republic of Poland (hereinafter, RP), the Russian Federation (hereinafter, RF) and Ukraine, and also to identify features of such regulations impact on the spread rates of COVID-19 coronavirus infection in these countries.

\section{MATERIALS AND METHODS}

This research is based on Belarusian, Kazakh, Moldavian, Polish, Russian and Ukrainian regulatory acts as well as scientific publications. Additionally, statistical data, expert opinions, judicial practices, doctrinal ideas and reviews on this issue has been used. Besides, the article is based on dialectical, comparative, analytic, synthetic, comprehensive, statistical analysis and generalization.

\section{REVIEW AND DISCUSSION}

On January 30, 2020, the World Health Organization declared an outbreak of coronavirus 2019-nCoV-2 "Public Health Emergency of International Concern" [8]. On 31 January 2020, WHO issued a "Global Surveillance for Human Infection with Novel Coronavirus (2019-nCoV): Interim Guidance" for Member States, providing recommendations to prevent outbreaks and/or rapid spread of a new infection in their territories [9]. The WHO then issues several other recommendations. All documents are periodically supplemented and adjusted to consider new information, in particular, on March 20, April 16, August 7 , etc. $[10 ; 11 ; 12]$. On March 11, 2020, the COVID-19 pandemic was declared [13]. However, to that date each of the countries of the world had different levels of readiness to fight this virus: some are better, others are worse, some countries decided to use an approach to develop collective immunity (for example, Sweden, Japan).

The actions of government agencies and special institutions involved in the fight, prevention and monitoring of the spread of infectious diseases in a given area were one of the indicators of each country's readiness to respond to epidemic threats. During the spread of COVID-19, the need for their existence and proper functioning in each country was obviously demonstrated.

It should be noted that the post-Soviet states partially borrowed the Soviet model of control over epidemic security, which was later reorganized. Thus, in Belarus, Kazakhstan, Moldova, Russia and Ukraine special bodies were created to address such health care issues as: 1) anti-epidemic measures, 2) infection control organization and 3) response to epidemic situations. Over time these bodies were transformed, and the areas of their activities changed. Thus, in Ukraine and Moldova, sanitary and epidemiological services were eliminated, and their functions were transferred to the bodies for which the fight against epidemic threats is not a priority.

In Belarus today, the system of sanitary control bodies is quite extensive and includes: The Hygiene, Epidemiology and Prevention Department of the Ministry of Health (hereinafter, the Ministry of Health); republican, regional centers of hygiene, epidemiology and public health; city, district, zonal hygiene and epidemiology centers in cities; disinfection and sterilization centers [14].

In the Republic of Kazakhstan, to date, the bodies of the sanitary-epidemiological service are: 1) branches of the Scientific and Practical Center for Sanitary-Epidemiological Examination and Monitoring; 2) state organizations involved in sanitary and epidemiological examination at the state border, in territories, transport facilities; 3 ) state organization that carries out sanitary and epidemiological examination during official events with the participation of state officials; 4) republican research organizations engaged in sanitary and epidemiological well-being activities, and 5) state anti-plague institutions [15].

In the Russian Federation, starting from 2004 till today the structure of control bodies of public health has included the Federal Service for the Oversight of Consumer Protection and Welfare responsible for, inter alia, sanitary and epidemiological supervision and control. Units in the federal subjects, Moscow and St. Petersburg, Hygiene and Epidemiology Centers, Research Institutes, hygiene and epidemiology related authorities, anti-plague institutions, sanitary and epidemiological services of ministries and departments are subordinated to the said Federal Service [16].

In the Republic of Poland, that is oriented towards the Western European countries, the State Sanitary Inspection is the leading body for ensuring the sanitary and epidemiological safety and security of the population, which implements the main functions through the Main Sanitary Supervision Body and the Sanitary and Epidemiological Council [17].

In our opinion, Moldova and Ukraine were among the most unprepared states in terms of combating coronavirus 2019-nCoV-2 due to the lack of a special state body to control the epidemic situation. Thus, in the Moldova, the State Sanitary and Epidemiological Service functioned within the structure of the Ministry of Health, Labor and Social Protection until 2010. However, at the time of the pandemic declaration, a separate body that would ensure the sanitary and epidemiological safety and security of the population was no longer available. Its functions were partly entrusted to the National Public Health Agency that is subjected to the Ministry of Health, Labor and Social Protection and having its own territorial offices. However, after the declaration of an emergency situation in Moldova the Public Health Institution "COVID-19 Center" was established in Chisinau [19]. 


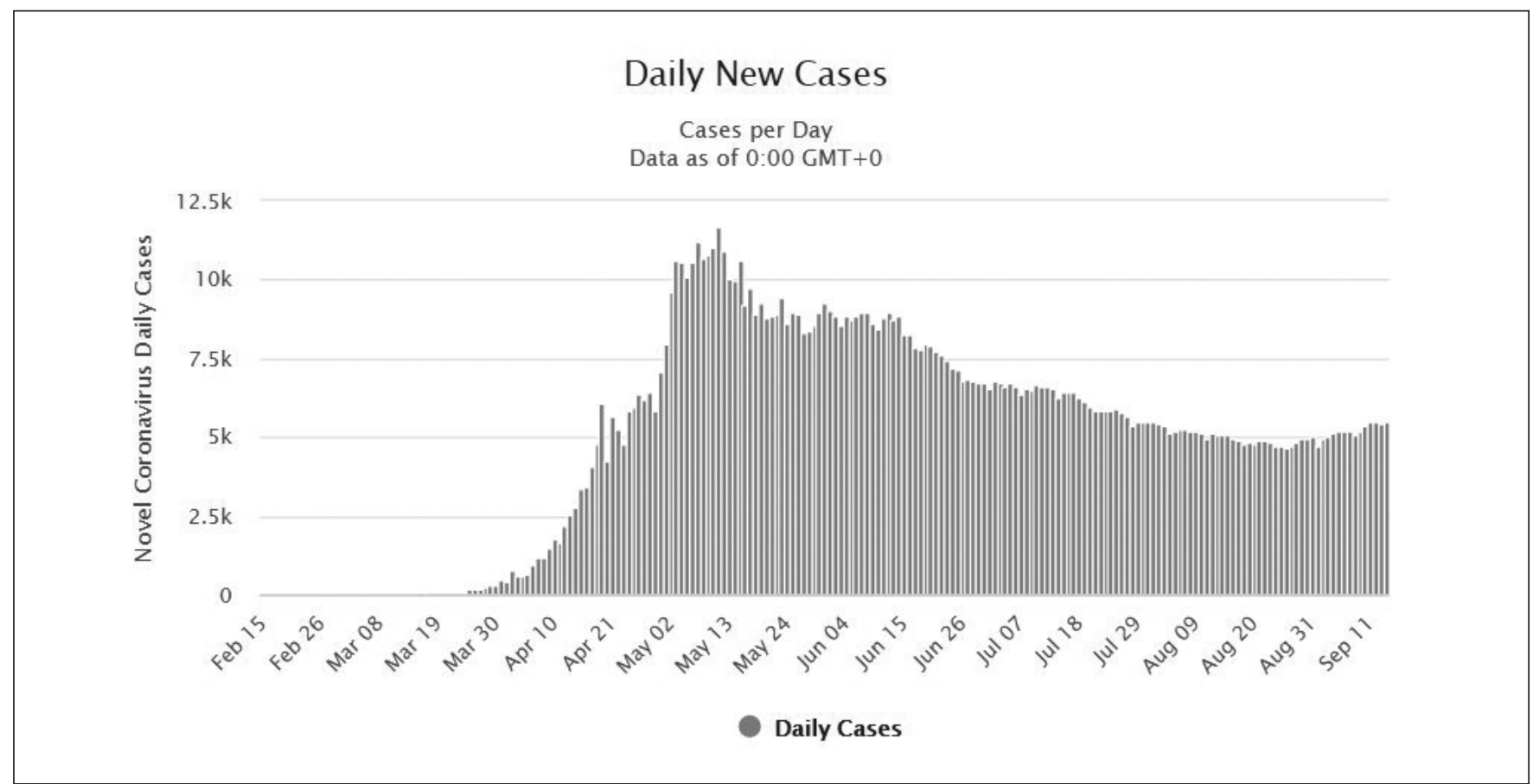

Fig. 1. Daily new cases in Russia. ${ }^{3}$

In Ukraine the functions of the State Sanitary and Epidemiological Service, which had been liquidated in 2017 and existed as a separate central executive body, were transferred to the Ministry of Health, the Ministry of Agrarian Policy and Food of Ukraine and the State Service for Food Safety and Consumer Protection. The dispersion of functions related to the control, prevention and monitoring of the spread of infectious diseases among institutions with other priority areas of activity led to a lack of comprehensive support for the epidemic security of the state. Therefore, on February 26, 2020, the position of Chief Sanitary and Epidemiological Doctor was restored in Ukraine. Today, the creation of a special state body to ensure sanitary and epidemiological security in Ukraine seems to be a cornerstone: the pandemic has shown that anti-epidemic measures, infection control and response to epidemic situations are vital for the effective health care policy in each country. Currently, the Government is considering options for establishing a service within the Ministry of Health. This once again confirms, in our opinion, the erroneousness and hastiness of the State Sanitary and Epidemiological Service elimination of in 2017. As rightly pointed out by Dr. T.A. Ghebreyesus, the WHO Director-General, "COVID-19 should be a lesson to all countries that health is not an 'either-or' equation. We must better prepare for emergencies but also keep investing in health systems that fully respond to people's needs throughout the life course" [7].

In addition to the functioning of special sanitary and epidemiological authorities, the measures implemented by the states to prevent the spread of COVID-19, the time of their implementation and the duration of such measures have also become a key to maintaining a safe (steady) level of morbidity. The red line among all quarantine restrictions

3 Hereinafter, graphs from the Worldometers web-site [21]. imposed in all states is: the obligation of persons arriving from foreign countries within 14 days from the date of arrival to self-quarantine at home (recommended by WHO on February 29, 2020) [20], and the ban on the export of medicines, medical products and equipment.

Russia was the first state to start implementing preventive measures. On January 24, 2020, the Federal Service for the Oversight of Consumer Protection and Welfare issued Resolution № 2 "On Additional Measures to Prevent the Spread of New 2019-nCoV-Coronavirus Infection". On January 29, the Interdepartmental Operational Headquarters was established. Moreover, the first cases of COVID-19 ( 2 people) were identified on January 31 in Russia. From that day on, due to the spread of coronavirus infection, the state began to gradually close its borders. Thus, on March 16, the Russian Government issued a resolution to close Russia's border with Belarus, the only country with no strict quarantine restrictions in its territory. It was also decided to limit the leisure of the country's population and sports events at all levels.

On March 25, when the number of new cases per day reached a rate of 163 and there were no coronavirus-related deaths [21], the Russian government declared the day-off period from March 30 till April 3 inclusive, which was then extended until April 30. Additionally, all life support structures (banks, shops, transport, pharmacies, medical institutions) and authorities at all levels continued to work. Additionally, by the Executive Order of the President of the Russian Federation dated April 02, 2020 № 239 “On ensuring people's sanitary and epidemiological welfare in view of coronavirus infection spread (COVID-19)", heads of regional administrations of the Russian Federation were given the discretion to impose restrictive measures, including restrictions of movements. Such rather mild quarantine 
regime seems to have resulted in a lack of positive dynamics in the number of new cases (see Figure 1). For example, on May 11, Russia ranked 3rd in the world by the number of cases (11,656 daily new cases and 94 daily new deaths [21]), due to the eased regime. However, some of the quarantine restrictions continued, in particular: restrictions for the elderly and those suffering from chronic diseases; ban on mass events; prolongation of the powers of the heads of regions to ease or strengthen restrictive measures, etc. This resulted in an improvement of the epidemic situation, partly due to the seasons change (warming), and as at $\mathrm{Au}$ gust 31,2020, there were 4,993 new cases of COVID-19, and 83 people died [21].

It should also be noted that among the measures aimed at combating coronavirus infection, Federal Laws dated April 01, 2020 № 99-FZ and № 100-FZ in the Russian Federation strengthened administrative ${ }^{4}$ and criminal liability for the violation of sanitary and epidemiological rules. According to the analysis of judicial practice, during the period from April 01, 2020 till August 31, 2020, Russian courts considered 16 criminal cases under Art. 236 "Violation of Sanitary and Epidemiological Rules" of the Criminal Code (hereinafter, the CC) of the Russian Federation. However, only 3 persons were convicted and imposed with a real sentence. Another 5 people were exempted from criminal liability under Art. 76.2 of the CC with the determination of a criminal law measure (court fine). Five materials of criminal cases were returned to prosecutors by courts. Nothing is known about the progress of 3 more cases. Much wider was the practice of administrative prosecution of persons under Part 2 of Art. 6.3 of the Code of Administrative Offenses (hereinafter, the CAO). In particular, 29, 742 administrative offense reports were issued. Among them, in 6,867 cases, individuals and legal entities were sentenced by the courts of the Russian Federation to an administrative fine, in 1,624 cases the proceedings were closed, in 1,638 cases the protocol was returned to the police, and in 231 cases the case was transferred to proper jurisdiction [22].

On January 26, 2020, the Republic of Kazakhstan strengthened sanitary and epidemiological control at checkpoints across the state border and held training exercises. Medical monitoring of persons arriving from China was also provided, and the 72-hour visa-free stay for Chinese citizens in Kazakhstan was suspended. On January 31, the second stage of strengthening sanitary and epidemiological control began: 150 sanitary and epidemiological service experts were sent to sanitary and quarantine points near the state border, laboratory diagnostics were established, clinical treatment protocols and algorithms of anti-epidemic measures were approved.
On March 13, the first 7cases of COVID-19 were identified and on March 14 there were 4 more, and on March 15 there were 6 more [21]. Therefore, on March 15, a state of emergency was declared in Kazakhstan, which was further extended until May 1. On April 27, the daily rate of new coronavirus cases reached 217 people [21], the authorities of the Republic of Kazakhstan decided to extend the state of emergency until 00:00 of May 11, while deciding to mitigate the quarantine regime in cities and regions. The situation with the spread of the virus was under control.

The easing of quarantine measures led to the announcement of a lockdown regime in Kazakhstan on July 5: all facilities were closed, except for supermarkets, pharmacies, cafes (with social distancing requirements), airports (domestic flights). It was caused by a sharp deterioration of the epidemiological situation and the rapid spread of the disease, as seen in Fig. 2. Such prompt and tough measures had a significant positive effect. Thus, as at August 31, 2020, the number of infected people decreased significantly to reach 111 new cases per day and the downward trend proceeded [21]. Despite the severity of the measures taken by the Government to stop the spread of coronavirus infection in the country, administrative and criminal liability for violating sanitary and epidemiological norms was not increased, due to sufficiency of punishment for such actions, according to the Kazakh legislator ${ }^{5}$.

Instead, from January till early March 2020, there were minor ("soft") restrictions on air travel and for persons who are "contact persons" or came from a country where there was an epidemic of coronavirus infection.

On March 2, the Sejm of the Republic of Poland approved the Law "On Special Decisions Related to the Prevention, Counteraction and Control of COVID-19, Other Infectious Diseases and Emergencies Caused by Them" (hereinafter, the Law of March 2, 2020), which entered into force on March 8,2020 . It created the possibility of using administrative, budgetary and anti-epidemic means to combat the spread of coronavirus. This Law also amended the provisions of the Law on Prevention and Control of Infections and Infectious Diseases, after which: a) the Council of Ministers was given the right to declare an epidemic or an epidemiological threat in certain parts of Poland or throughout Poland; b) public authorities have the right to establish 3 different zones (zero level, buffer and danger zones) at the site of the epidemic outbreak, which differ in the level of restrictions associated with the risk of an epidemic in each area [23].

On March 4, the Ministry of Health of the Republic of Poland reported the first case of SARS-CoV-2. After that, the state began to gradually tighten quarantine restrictions. Thus, on March 8, the Chief Sanitary Inspector recommended the cancellation of all mass events involving more than 1,000

\footnotetext{
${ }^{4}$ Art. 6.3 of the $\mathrm{CAO}$ of the RF was supplemented by Part 2, establishing more severe penalties for violations of current sanitary rules and hygiene standards, non-compliance with sanitary and anti-epidemic measures, etc., committed during an emergency or at risk of spreading a disease that poses public danger or during the implementation of restrictive measures (quarantine) in the relevant territory.

${ }^{5}$ The administrative liability under Art. 425 "Violation of the Requirements of the Legislation in the Field of Sanitary and Epidemiological Well-Being of the Population, and also Hygienic Standards" of the CAO of the RK, Art. 476 "Violation of the State of Emergency" of the CAO of the RK and Art. 304 "Violation of Sanitary Rules or Hygienic Standards" of the CC of the RK.
} 


\section{Daily New Cases}

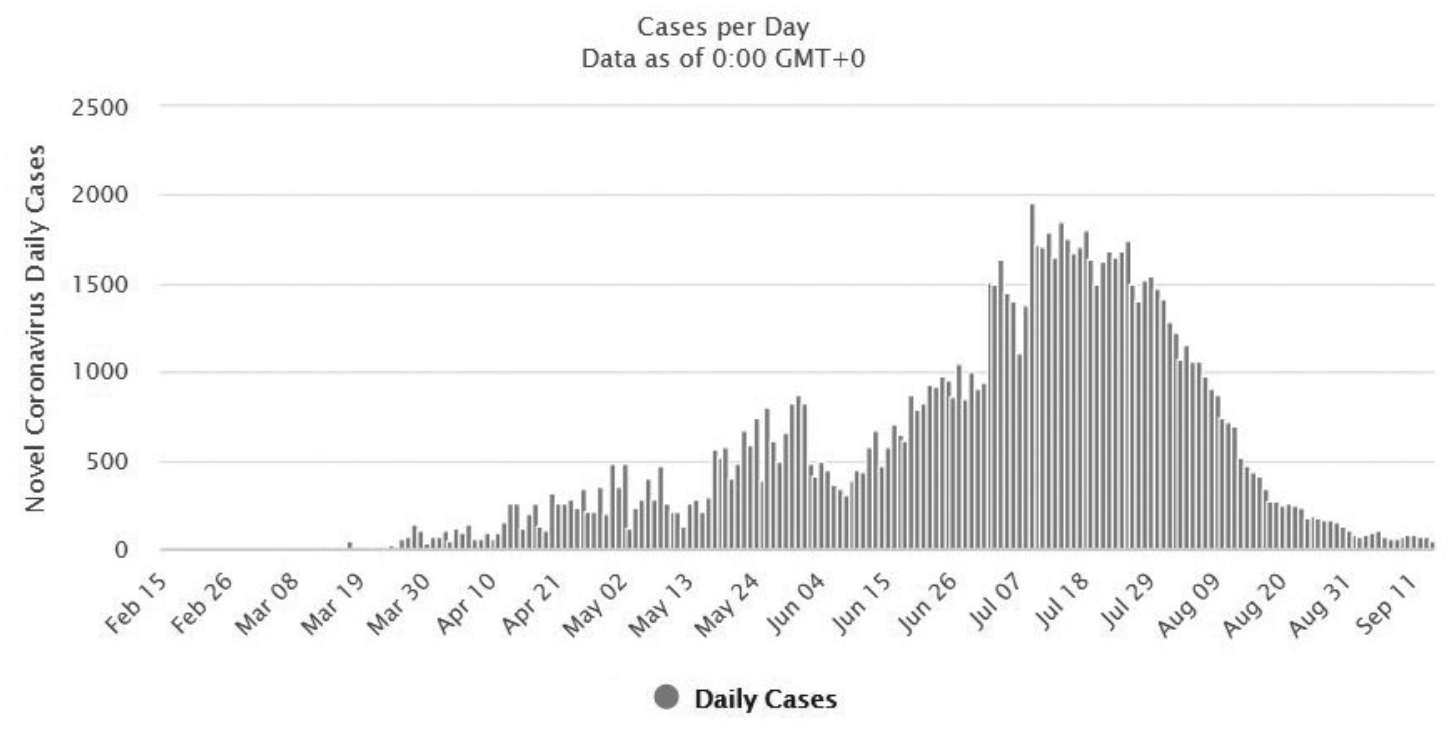

Fig. 2. Daily new cases in Kazakhstan.

\section{Daily New Cases}

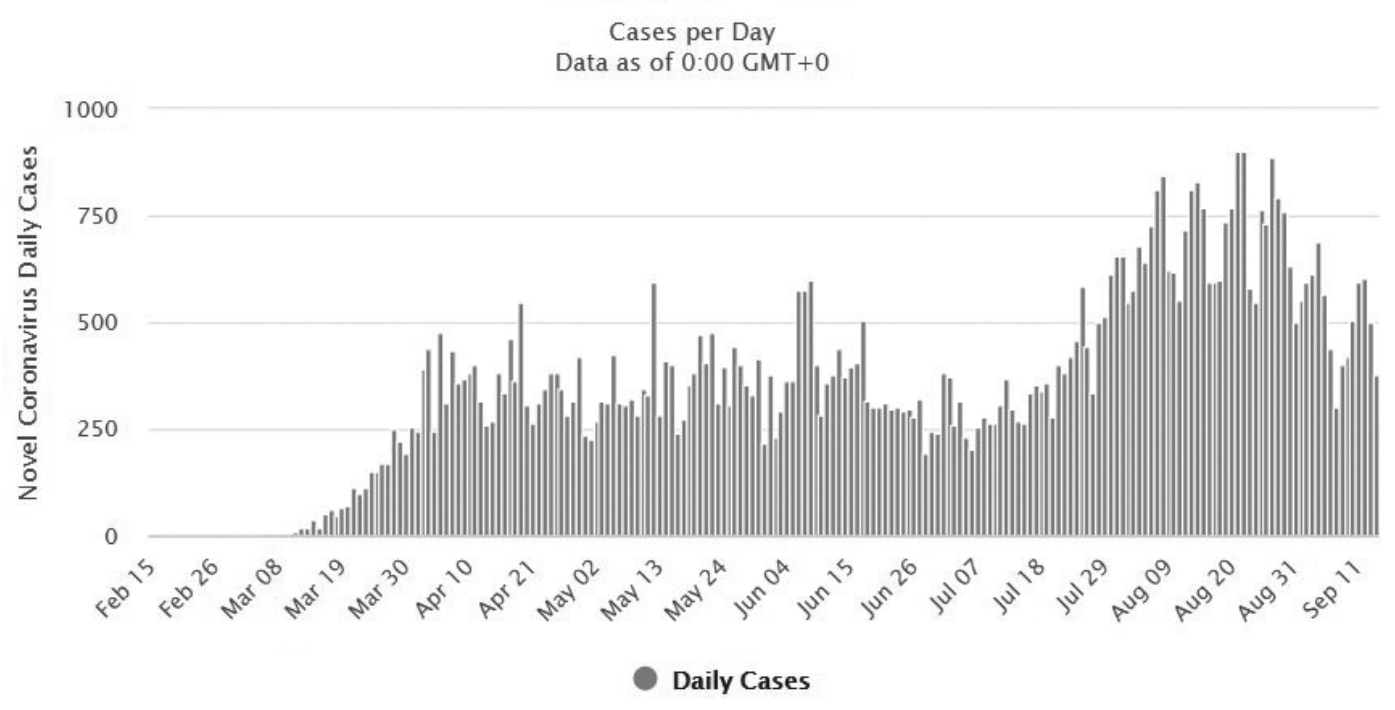

Fig. 3. Daily new cases in Poland.

people indoors. A meeting of the National Security Council on countering the spread of coronavirus in the country was held on March 10, and the Prime Minister of Poland canceled all mass events. On March 11, all schools, kindergartens, nurseries, and secondary schools were closed, except for special schools, institutions for the education of children with special needs and sociotherapy facilities, psychological and pedagogical centers, as well as schools in correctional facilities and prisons (from March 12 until March 25, 2020). An epidemic was officially declared on March 20, and the next day Poland had 111 new cases of COVID-19. From March 24, a lockdown was introduced (152 daily new cases and 2 daily new deaths [21]), which lasted until April 11. However, on March 31, the restrictions became even stricter, since as of March 30, Poland faced 193 daily new cases and 9 daily new deaths. On April 10, there was a slight easing, despite the fact that the rates increased ( 380 daily new cases and 9 daily new deaths [21]). In general, most restrictions were extended until May 3. Then, as can be seen from Fig. 3, Poland experienced a periodic fluctuation in the number of new cases in-line with increasing/decreasing of restrictive measures in certain areas. In particular, new restrictions are to apply in 19 poviats from August 8, which were related to two zones: yellow and red.

The Republic of Poland also strengthened criminal and administrative liability for violating quarantine restrictions. Thus, the Law of March 31, 2020 "On Amendments to 
the Law on Special Decisions Related to the Prevention, Counteraction and Control of COVID-19, Other Infectious Diseases and Crisis Situations Caused by Them and Certain Other Acts" amended Art. 161 of the CC of the Republic of Poland with a new wording. In this case, according to Polish researchers, the changes cause numerous corpus delicti comments $[24 ; 25]$. It is noteworthy that, unlike the legislation of other countries to be analyzed, criminal prosecution of a guilty person in Poland for creating a risk of coronavirus infection of one person starts only at the request of the victim ( $\$ 4$ of Article 161 of the CC). For such actions the guilty person faces imprisonment for a term of 3 months up to 5 years, while the risk of infecting several people provides imprisonment from 1 up to 10 years, which is the most severe punishment among the countries we analyze ${ }^{6}$. Poland increased administrative liability for violating quarantine restrictions, where fines increased to 30,000 zlotys. The amount of the fine under Art. 116 of the Code of Minor Offenses depends on the agency that imposes these sanctions. If the police "fine on the spot", then fine will be 500 zlotys (for each violator), if the case is passed on to the sanitary services or court, then higher fines are applied [26].

It was the imperfection of the criminal norm and its significant severity that can be explained by the fact that as of August 31, 2020 the courts of Poland did not pass a single conviction under $\$ 2$ of Art.161 of the CC [27].

Ukraine faced one of the most difficult situations among the countries under study, due to the fact that at the time of the rapid spread of COVID-19 it did not have a functioning State Sanitary and Epidemiological Service. Moreover, since January, the airlines have gradually canceled flights to countries with a large number of coronavirus cases.

On February 26, the post of Chief Sanitary and Epidemiological Doctor was restored in Ukraine and already on March 3 the first case was found, and since March 10 there was a gradual increase in the number of new cases. On this background, on March 11, the Cabinet of Ministers of Ukraine introduced quarantine from March 12 till April 3, which in fact lasts to this very day. On March 25, due to the steady increase in the number of new cases (43 daily new cases and 2 daily new deaths [21]), the Government introduced a state of emergency throughout Ukraine until April 24,2020 , during which the authorities and civil protection services had to work in an enhanced mode and there was no provision for state intervention in the management of private companies or restrictions on the rights of citizens. On April 6, due to the epidemic situation (as at April 5, 83 daily new cases and 5 daily new deaths were detected [21]), new restrictive quarantine measures were introduced in Ukraine: a ban on visiting parks and recreation areas, mandatory wearing of masks in public places, persons over 60 years old were recommended to stay at home, which were subsequently extended until May 11 without mitigation. Subsequently, the Government presented a 5-stage plan for the country's quarantine, which began to be implemented on May $7^{7}$. In the summer, the list of quarantine restrictions constantly changed depending on number of new cases. Finally, from August 1, the quarantine rules in Ukraine have been changed: all regions were divided into green, yellow, orange and red zones, each of which provided for a different amount of quarantine restrictions. Such measures, although difficult for society to accept, generally affected, in our view, the containment of the infection. As can be seen from Fig. 4, it was only in autumn that the daily morbidity rates began to grow.

On March 17, Law of Ukraine "On Amendments to Certain Legislative Acts of Ukraine Aimed at Preventing the Occurrence and Spread of Coronavirus Disease (COVID-19)" № 530-IX strengthened criminal liability for the violation of sanitary and epidemiological rules (Art. 325 "Violation of Sanitary Rules and Norms for the Prevention of Infectious Diseases and Mass Poisoning" of the CC), which was also rightly negatively assessed by scientists [28, pp. 101-106; 29, pp. 237-240]. In addition, administrative liability was introduced for such actions: the CAO of Ukraine was supplemented by Art. 44-3 "Violation of the Rules on Quarantine of People", which imposed too severe penalties, and therefore, according to the analysis of case law, in the vast majority of cases judges limited punishment to the announcement of oral warning notice ${ }^{8}$.

If we consider the trend of the disease spread in Moldova, which, like Ukraine there, had no special state body to control the epidemic situation, it should be noted that the situation in this small country is even worse and according to official data the percentage of infected persons is the highest. On February 25, 2020, some anti-coronavirus measures were introduced, in particular, persons crossing the border and under suspicion were subject to isolation. The first case of COVID-19 was found on March 7. On March 8, the Emergency National Public Health Commission issued an orange code warning at the national level in the context of the epidemic. The Red Code was announced on March 13 , and 11 daily new cases were identified on March 15 . As the number of new cases began to increase, on March 17 the Parliament declared a state of emergency throughout Moldova until May 15. Despite these measures, the total number of patients (Total Cases) increased to 109 people on

\footnotetext{
${ }^{6}$ The most severe criminal punishment, which is established in the criminal laws of Belarus, Moldova and Ukraine, for the spread of coronavirus infection among the population, and sometimes for creating a real threat of its spread, is imprisonment for up to 3 years. The criminal legislation of the RK and the RF provides for up to 2 years of imprisonment.

${ }^{7}$ As of May 6, 2020, 487 daily new cases and 11 daily new deaths were identified.

${ }^{8}$ Thus, the data of the Unified State Register of Court Decisions of Ukraine show that in the period from March18, 2020 till August 31, 2020, 2,370 people were found guilty of committing an administrative offense under Art. 44-3 of the CAO of Ukraine. Analysis of 100 of these resolutions shows that: a) an administrative penalty in the form of a fine was imposed on 26 persons, of which 25 persons were fined in the amount equivalent to UAH 17,000, 1 person was fined in the amount equivalent to UAH 34,000 ; b) 73 persons were released from administrative liability due to the insignificance of the act with the announcement of oral remarks. Another case was closed [30]
} 


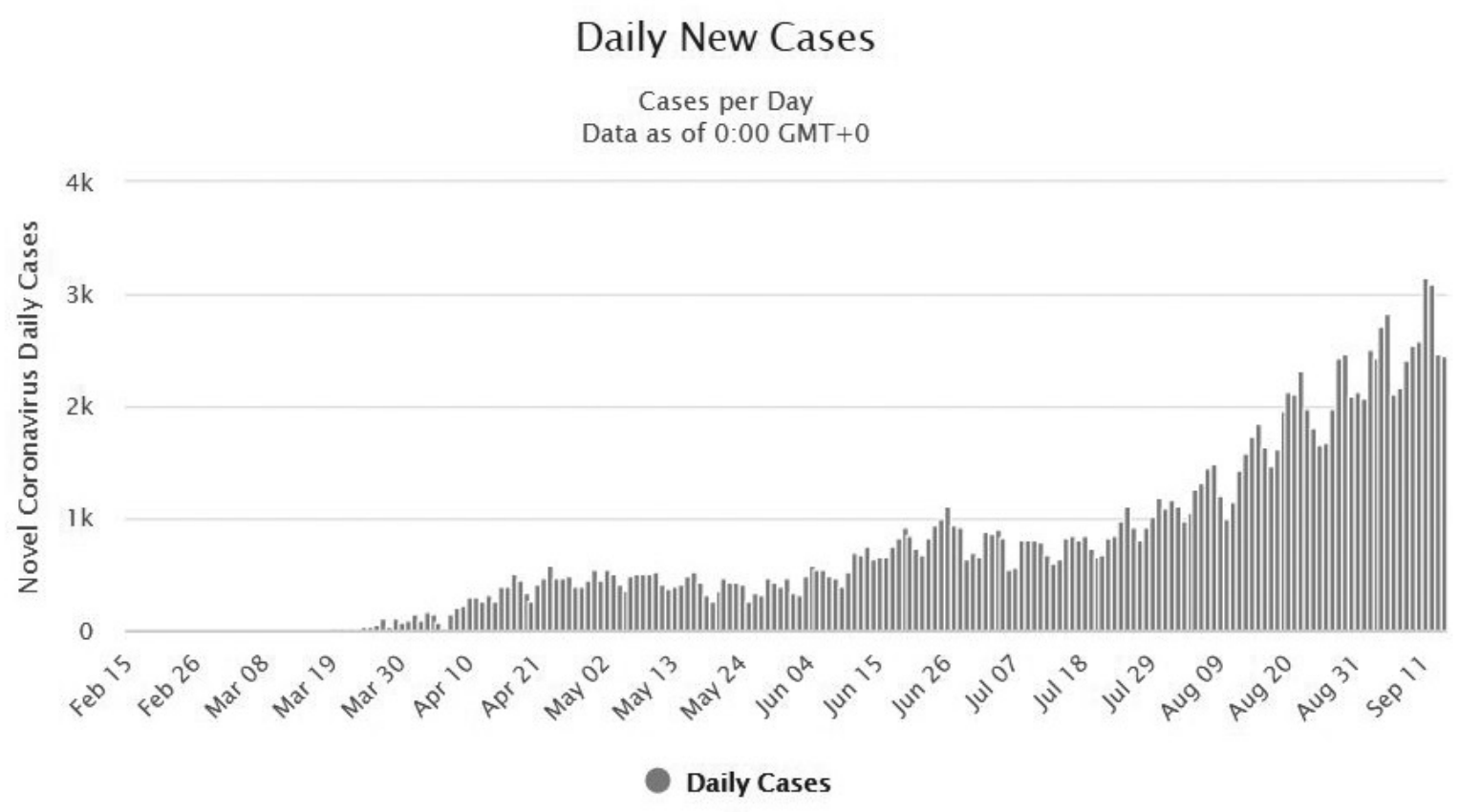

Fig. 4. Daily new cases in Ukraine.

March 23 and to 1,056 cases on April 7 [21]. On April 27, the total number of deaths exceeded 100. A public health emergency was declared in Moldova starting on May 16 and quarantine restrictions were partially decreased, and despite a sharp increase in the number of patients (189 daily new cases and 5 daily new deaths [21]), the authorities did not strengthen quarantine and generally extended the state of emergency until August 31.

In Moldova, Law of March 12, 2020 № 52 “On Amendments to Certain Regulations" also not only strengthened criminal liability for the spread of epidemic diseases (Art. 215 of the CC), but also amended the Code of Offenses of the Republic of Moldova with the Art. 76-1 "Failure to Comply with Measures for the Prevention, Counteraction and/or Control of Epidemic Diseases".

However, all these quarantine restrictions do not seem to have improved the situation (Fig. 5). The reasons for this can be seen, according to E. Goloshchapov, in the fact that people ignore safety measures in the hot weather conditions [31].

Belarus is a special case in terms of the countries studied. Thus, the first case of COVID-19 in Belarus was detected on February 28, 2020. As of March 11, there were 9 cases, and on March 12 there were already 21 cases of coronavirus [21]. But only on March 12, the Council of Ministers decided to limit all cultural, sporting and scientific events with international participation until April 6. From March 13, railway and air transport communication with many foreign countries was suspended. However, these measures could not limit the rapid spread of the infection and as of March 13, 27 Total Cases had already been identified. March 23 was marked by 81 cases, of which only 5 daily new cases [21]. On March 25, the Minister of Health of stated that he would no longer update the map of the spread of coronavirus infection, explaining it by the need to protect the rights of patients. However, fig. 6 clearly shows that the morbidity rates subsequently increased rapidly.

Also, Resolution of the Council of Ministers of March 25, 2020 № 171 defined measures to prevent the spread of infection caused by COVID-19, but these restrictions can be assessed as mild. It is noteworthy that, unlike other states, the authorities did not cancel the May 9 Parade dedicated to the Victory Day, although veterans were urged to stay at home and not to attend mass events. On May 12 in comparison to May 6 the number of cases considerably increased (from 905 to 967 daily new cases [21]).

Generally, when assessing the morbidity rates in Belarus, a remark should be made - they are quite relative. Thus, the National Statistical Committee of Belarus did not publish official data on mortality in the country for the first half of 2020, but based on information provided to the UN, in April-June mortality exceeded the average for the last 5 years by about 5,500 people. [32]. Reasons for such a rapid growth is not specified, but this information suggests that the epidemic of coronavirus infection is also raging in $\mathrm{Be}$ larus. However, according to official statistics, as at August $31,71,843$ people got infected with COVID-19 in Belarus [21]; according to Figs. 6, the morbidity rate since July has been consistently low.

Belarus has also become another country where neither administrative nor criminal liability for violating sanitary and epidemiological rules has been strengthened.

The analysis showed that the amount of restrictive measures imposed in all the countries studied was different at over time. It is seen that a number of factors has played a 


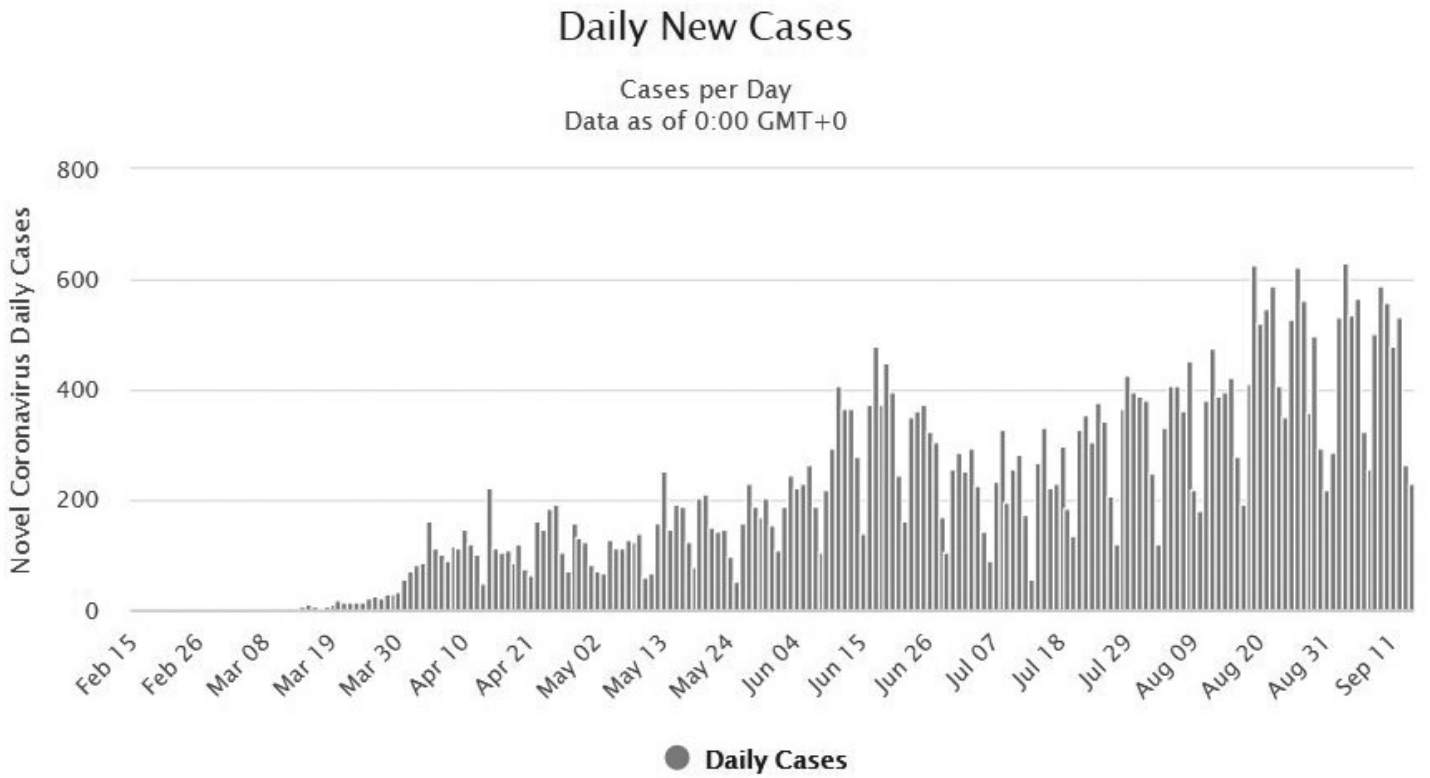

Fig. 5. Daily new cases in Moldova.

\section{Daily New Cases}

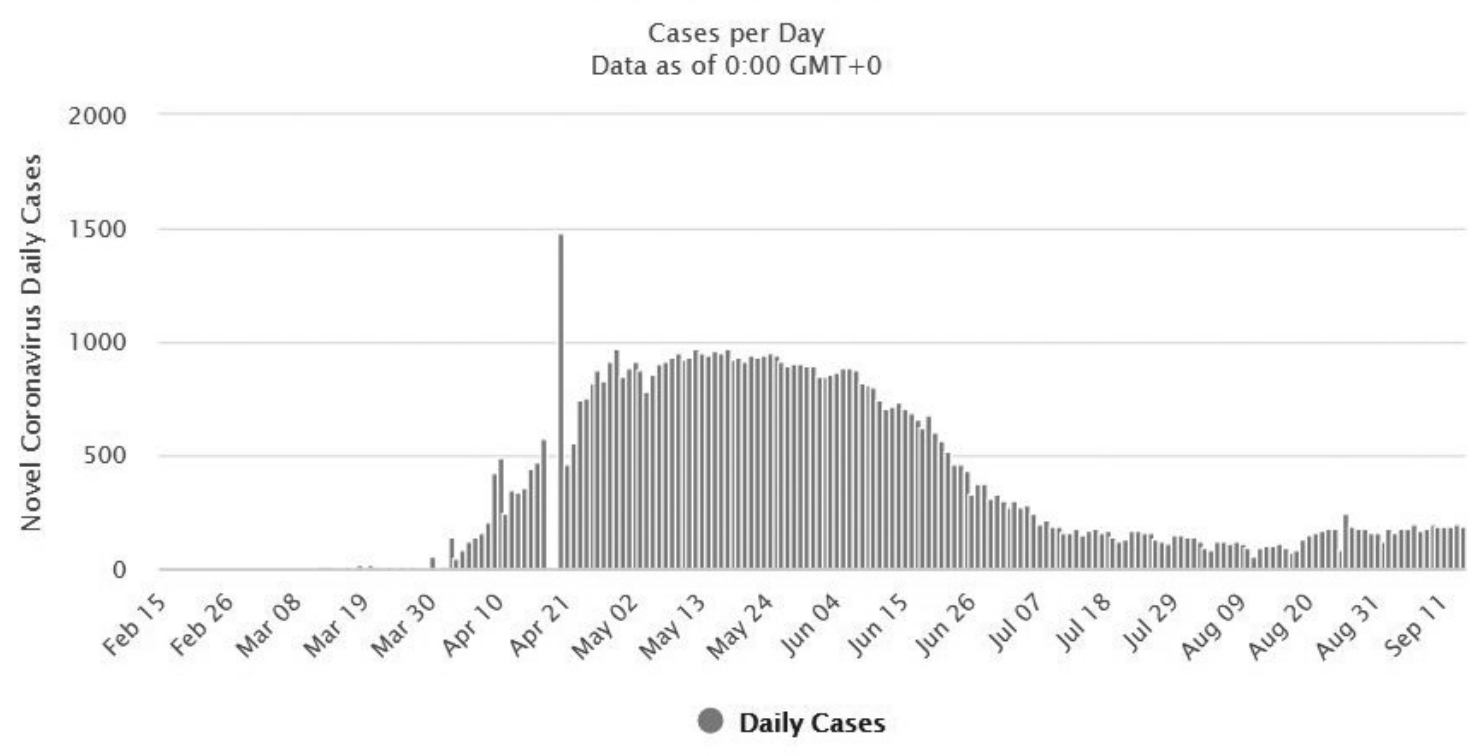

Fig. 6. Daily new cases in Belarus.

role in this process. In particular, the proximity to a country with a high morbidity rate, the COVID-19 spread rate within a certain area, the country's readiness to fight the coronavirus, the availability of places in hospitals, lung ventilators, health workers, protective equipment and others. Moreover, the time to implement these measures, their duration, level of perception and compliance by the population were of importance for the effective counteracting of the spread of coronavirus infection in a certain area. As a result, the quantitative indicators of COVID-19 cases as of August 31, 2020 were different for each of the analyzed countries, as shown in Table I.

These indicators make it clear that as of August 31, 2020 in Belarus $0.76 \%$ of the population was infected, of which $0.007 \%$ died, these figures were $0.562 \%$ and $0.008 \%$ in Kazakhstan; $0.916 \%$ and $0.025 \%$ in Moldova; $0.178 \%$ and $0.005 \%$ in Poland; $0.682 \%$ and $0.012 \%$ in Russia and $0.278 \%$ and $0.006 \%$ in Ukraine, respectively. 
Table. I. Indicators COVID-19 cases as of August 31, 2020

\begin{tabular}{cccc}
\hline Country & Total Cases $^{1}$ & Total Deaths & Population \\
\hline Belarus & 71843 & 681 & 9448781 \\
\hline Kazakhstan & 105795 & 1523 & 18814618 \\
\hline Moldova & 36920 & 995 & 4032320 \\
\hline Poland & 67372 & 2039 & 37839368 \\
\hline Russia & 995319 & 17176 & 145945354 \\
\hline Ukraine & 121215 & 2557 & 43657291 \\
\hline
\end{tabular}

\section{CONCLUSION}

Thus, it should be noted that it will take time for the world to overcome the negative consequences of the SARS-Cov-2 virus. The study showed that the state of epidemic safety and security during the COVID-19 pandemic was significantly affected by: 1) the presence of government agencies and/ or special institutions involved in combating, preventing and monitoring the spread of infectious diseases, 2) their readiness to operate effectively in emergencies situations caused, in particular, by epidemics, 3) the severity of the implemented quarantine measures, 4) the level of perception and compliance with security measures by the population, and 5) the effectiveness of law enforcement response to their violations. In addition, restraining the rate of coronavirus infection spread in a particular state depended on the timeliness of such restrictions and the time of their decreasing. It was also found that increased criminal and administrative liability for violating quarantine measures failed to become an effective tool to curb the spread of the disease. This is because the preventive effect is not so much dependent on the severity of punishment, but rather on the inevitability of its application to the perpetrator as well as the attitude of the population to the quarantine restrictions and good faith compliance.

\section{REFERENCES}

1. Managing epidemics: key facts about major deadly diseases/Edited by:T. Prentice. 2018:260. Available from: https://www.who.int/emergencies/ diseases/managing-epidemics-interactive.pdf [reviewed 2020.06.30].

2. Farouq Ahmad FalehAlazzam, Ali Jabbar Saleh, Khaled Khalaf Abed Rabbo Aldrou. Impact of pandemic COVID-19 on the legal regulation of world trade activity using the example of the medical supplies. Wiad Lek. 2020;7:1521-1527. doi: 10.36740/WLek202007139

3. Radish Y., Moisejenko R., Mykhalchuk V. Human health as a philosophic phenomenon and an important component of national security and state sovereigntypotential. Wiad Lek.2020;5:994-999. doi:10.36740/WLek202005129

4. Statement of the World Health Organization on allegations of conflict of interest and 'fake' pandemic. January 22, 2010. Available from: https://www.who.int/mediacentre/news/statements/2010/ h1n1_pandemic_20100122/en/ [reviewed 2020.06.30].

5. Savage S. H1N1 Still A Pandemic, Says WHO. July 20, 2010. Available from: https://www.redorbit.com/news/health/1893907/h1n1_ still_a_pandemic_says_who/[reviewed 2020.06.30].
6. Dawood F. S., Iuliano A.D., Reed C., et al. Estimated global mortality associated with the first 12 months of 2009 pandemic influenza A H1N1 virus circulation: a modelling study. The Lancet Infectious Diseases. Published: June 26, $2012 \mathrm{https}: / /$ doi.org/10.1016/S14733099(12)70121-4 Available from: https://www.thelancet.com/ journals/laninf/article/PIIS1473-3099(12)70121-4/fulltext [reviewed 2020.06.20].

7. In WHO global pulse survey, $90 \%$ of countries report disruptions to essential health services since COVID-19 pandemic 31 August 2020. Health Organization. Available from: https://www.who.int/news/ item/31-08-2020-in-who-global-pulse-survey-90-of-countriesreport-disruptions-to-essential-health-services-since-covid-19pandemic [reviewed 2020.08.31].

8. Statement on the second meeting of the International Health Regulations (2005) Emergency Committee regarding the outbreak of novel coronavirus (2019-nCoV). WHO. January 30, 2020. Available from: https://www.who.int/news-room/detail/30-01-2020-statement-onthe-second-meeting-of-the-international-health-regulations-(2005)emergency-committee-regarding-the-outbreak-of-novel-coronavirus(2019-ncov) [reviewed 2020.06.30].

9. Global Surveillance for human infection with novel coronavirus (2019nCoV): interim guidance, 31 January 2020. World Health Organization. Available from: https://apps.who.int/iris/handle/10665/330857 [reviewed 2020.06.30].

10. Global surveillance for COVID-19 caused by human infection with COVID-19 virus: interim guidance, 20 March 2020. World Health Organization. Available from: https://apps.who.int/iris/ handle/10665/331506 [reviewed 2020.06.30].

11. Considerations in adjusting public health and social measures in the context of COVID-19: interim guidance, 16 April 2020. World Health Organization. Available from: https://apps.who.int/iris/bitstream/ handle/10665/331773/WH0-2019-nCoV-Adjusting_PH_measures2020.1-eng.pdf [reviewed 2020.06.30].

12. Public health surveillance for COVID-19: interim guidance, 7 August 2020. World Health Organization. Available from: https://www.who. int/publications/i/item/who-2019-nCoV-surveillanceguidance-2020.7 [reviewed 2020.08.20].

13. WHO Director-General's opening remarks at the media briefing on COVID-19. March 11, 2020. Available from: https://www.who.int/dg/ speeches/detail/who-director-general-s-opening-remarks-at-themedia-briefing-on-COVID-19---11-march-2020 [reviewed 2020.06.30].

14. Sany'tarnaya sluzhba. Ofycyalnyj sajt Ministerstva zdravooxraneniya RB [Sanitary service. Official site of the Ministry of Health of the Republic of Belarus]. Available from: http://minzdrav.gov.by/ru/ ministerstvo/struktura/sanitarnaya-sluzhba/index.php [reviewed 2020.06.30] (Be).

15. Sanitarno-karantynnyj kontrol: vidy i meropriyatiya. [Sanitary and quarantine control: types and activities]. Available from: https:// egov.kz/cms/ru/articles/sanitation/sanitarno_karantiyniy_control [reviewed 2020.07.30] (Ru).

16. Ob utverzhdenii Polozheniya o Federal'noj sluzhbe po nadzoru v sfere zashchity prav potrebiteleji blagopoluchiya cheloveka (s izmeneniyami na 30 aprelya 2020 goda) [On approval of the Regulations on the Federal Service for Supervision of Consumer Rights Protection and Human Wellbeing (as amended on April 30, 2020)] Available from: http:// docs.cntd.ru/document/901901771 [reviewed 2020.07.30] (Ru).

${ }^{9}$ Data from the Worldometers web-site [21]. 
17. Główny Inspektorat Sanitarny. Available from: https://www.gov.pl/ web/gis/podstawowe-informacje [reviewed 2020.07.30].

18. ZAKON o gosudarstvennom nadzore za obshchestvennym zdorov'em № 10 ot 03-02-2009 Available from: https://www.legis.md/cautare/ getResults?doc_id=122828\&lang=ru\# [reviewed 2020.07.30] (Ru).

19. Komissiya po chrezvychajnym situaciyam Respubliki Moldova RASPORYAZHENIE № 10 ot 31 marta 2020 g. [Emergency Situations Commission of the Republic of Moldova ORDER No. 10 of March 31, 2020] Available from: https://cancelaria.gov.md/sites/default/files/ rasporyazhenie_no_10_ot_31_marta_2020_g._komissii_po_ chrezvychaynym_situaciyam_respubliki_moldova.pdf [reviewed 2020.07.30] (Ru).

20. Considerations for quarantine of individuals in the context of containment for coronavirus disease (COVID-19): interim guidance, 29 February 2020. World Health Organization. Available from: https:// apps.who.int/iris/handle/10665/331299 [reviewed 2020.06.30].

21. Coronavirus. Worldometer. Available from: https://www.worldometers. info/coronavirus/ [reviewed 2020.08.31].

22. Sudebnye reshenyia RF [Court judgments of the Russian Federation]. Available from: http://xn--90afdbaav0bd1afy6eub5d.xn--p1ai/ [reviewed 2020.07.30] (Ru).

23. Coronavirus COVID-19 outbreakin the EUFundamental Rights Implications. Available from: https://fra.europa.eu/en [reviewed 2020.08.30].

24. Kubiak R. Odpowiedzialność karna za narażenie na zakażenie wirusem SARS-COV-2. Palestra. 2020; 6 Available from: https://palestra.pl/pl/ czasopismo/wydanie/6-2020/artykul/odpowiedzialnosc-karna-zanarazenie-na-zakazenie-wirusem-sars-cov-2 [reviewed 2020.08.10].

25. Malecki M., Slawinski M. The repressive Nature of Selected COVID-19 Regulations in the Polish Legal System. Coronavirus and the Law in Europe. 2020. Available from: https://www.intersentiaonline. com/bundle/coronavirus-and-the?fbclid=IwAR1sH4dIPwYGFF dU0xENje3APeQsS2LdXinXKUuqScJmgFMZiW4hv7fEFA [reviewed 2020.08.10].

26. Za narushenie karantina v Pol'she pridetsya zaplatit' shtrafilisest' v tyur'mu. [For violation of quarantine in Poland, you will have to pay a fine or go to jail.] Available from: https://poland-consult.com/coronavirus/shtrafy-vpolshe-za-narushenie-karantina.html [reviewed 2020.08.03] (Ru).

27. Portal Orzeczeń Sądów Powszechnych. Available from: http:// orzeczenia.ms.gov.pl/search/advanced [reviewed 2020.08.10].

28. Zhytnyi 0. 0., Yemelianenko V. V. Problemy dii u chasi ta prostori kryminalno-pravovykh zasobiv zabezpechennia epidemichnoi bezpeky [Problems of action in time and space of criminal legal means of equipment of epidemic security]. Pravovi zasady epidemichnoi bezpeky: vyklyky ta perspektyvy : internet-konferentsiia (Poltava, 29 kvitnia 2020). Kharkiv : Pravo. 2020: 101-105 (Ua).

29. Ponomarenko Yu. A. Pro deiaki zakonodavchi novely kryminalnoi vidpovidalnosti za porushennia sanitarnykh pravyl i norm shchodo zapobihannia infektsiinym khvorobam ta masovym otruienniam [About some legislative news of criminal responsibility for violation of sanitary rules and standards on prevention of infectious diseases and mass poisoning]. Pravovi zasady epidemichnoi bezpeky: vyklyky ta perspektyvy : internet-konferentsiia (Poltava, 29 kvitnia 2020). Kharkiv : Pravo. 2020: 237-240. (Ua).
30. Yedynyi derzhavnyi reiestr sudovykh rishen [Single State Register of judgments] Available from: http://reyestr.court.gov.ua/ [reviewed 2020.08.07]. (Ua).

31. Semenova Yu. Koronavyrus v Moldavyy: zabolevshykh vse bolshe, ohranychenyi vse menshe [Coronavirus in Moldova: more and more cases, fewer restrictions]. DW. June 30,2020. Available from: https://p. dw.com/p/3eWl0 [reviewed 2020.08.10] (Ru).

32. Deaths by month of death : record view. UNdata. 2020. Available from: http://data.un.org/Data.aspx?q=deaths+by+month\&d=POP $\& \mathrm{f}=$ tableCode:65; countryCode:112;refYear:2010,2011,2012, $2013,2014,2015,2016,2017,2018,2019,2020 \& c=2,3,8,13,14 \& s=$ countryEnglishName0rderBy:asc,refYear:desc,areaCode:asc\&v=1 [reviewed 2020.08.31].

The scientific paper is prepared pursuant to the fundamental scientific researches of Yaroslav Mudryi National Law University "Theoretical problems of efficiency of the criminal legislation of Ukraine and practice of its application" (state registration № 0111u000959) and Academician Stashis Scientific Research Institute for the Study of Crime Problems, National Academy of Law Sciences of Ukraine "Challenges of Ukraine's modern criminal law doctrine formation" (state registration №: 0117U000285).

\section{ORCID and contributionship:}

Yuliia Yu. Zabuha: 0000-0003-1956-2233 B, D, E, F

Tetiana O. Mykhailichenko: 0000-0002-4668-3375 C, D, E, F

Svitlana V. Rak: 0000-0001-8095-9681 A, D, E, F

\section{Conflict of interest:}

The Authors declare no conflict of interest.

\section{CORRESPONDING AUTHOR Yuliia Yu. Zabuha \\ Yaroslav Mudryi National Law University, Pushkinskaya str., 77, 61024, Kharkiv, Ukraine e-mail:zabugaulia1@gmail.com}

Received: 26.08 .2020

Accepted: 30.11 .2020

\footnotetext{
A - Work concept and design, B - Data collection and analysis, C - Responsibility for statistical analysis, D -Writing the article, $\mathbf{E}$ - Critical review, $\mathbf{F}$ - Final approval of the article
} 